\title{
SHARED EXPERIENCES: INTERACTIONS OF ABORIGINAL PEOPLES AND THE 'OUTSIDERS'
}

\author{
Elspeth Young
}

This volume of Aboriginal History presents a diverse group of papers concerned with historical and political issues and experiences of aboriginal peoples in their interactions with the 'outsiders', the adventurers, government officers, traders and settlers who came uninvited into their countries from foreign lands. They focus not only on indigenous Australians but also on indigenous minorities in New Zealand, Canada, the United States of America and Norway. While some papers deliberately use comparative approaches in their discussion others concentrate on only one of these regional settings, leaving the reader to draw out some of the similarities and differences for him or herself. The lengthy gestation of this collection reflects the complexities of bringing together papers from such a diverse range of authors, some of whom responded to initial calls for papers and others of whom fortuitously happened to submit papers which coincided with this theme. I hope that the final collection is not only of interest but also generates further inquiries which may lead to more discussion on these topics in future.

Common themes highlighted in this collection of papers include the early contact experiences of indigenous groups with explorers, traders and others; the process and effects of land alienation, land rights recognition and negotiations; the impact of assimilationist policies; and the realities of contemporary indigenous international networks.

\section{Early contact experiences}

Two papers - Baker and Scott - use very different types of information to describe early contact experiences. Baker, using Thomas Mitchell's journals of his travels in Australia and Lewis and Clark's accounts of their journeys in North America, presents the explorers' perspective and speculates on the similarities and differences between these frontier experiences. An interesting contrast was the close interaction between the American explorers and the Indian peoples whom they encountered, demonstrated by the explorers' willingness to live off local natural resources and mix with their 'hosts'; and the deliberate distancing of Mitchell and his party from such contact, an approach which made their survival in the 'bush' much more precarious. On the other hand both Mitchell and Lewis and Clark stress the common assumption on the part of the Indian and Aboriginal groups whom they met that the strangers were 'spirits'. Scott, using Cree narrative histories and mythologies, confirms the persistence of such beliefs and speculates on the importance of reciprocal behaviours in enabling relatively peaceful contact with the 'whiteman'.

\section{Land Alienation, Land Rights Recognition and Negotiation}

Craufurd-Lewis' overview of the development of treaties in Australia, New Zealand, Canada and the United States of America explores contrasts in the perceptions of the value

Elspeth Young, a geographer and currently Director, Graduate Studies in Environmental Management and Development at the Australian National University, has worked with Aboriginal groups in central and northern Australia and has conducted comparative research with indigenous peoples in northern Canada, Alaska and Botswana. Her main research interests include contemporary indigenous land management and appropriate planning for indigenous community development. 
of the assets which the indigenous customary landholders brought to negotiation with the land hungry 'outsiders, and how differences in these perceptions affected the processes of land acquisition. Parallel themes revealed in all four countries include the deliberate extermination and 'invisibility' of indigenous 'first peoples', policies of assimilation, sometimes including slavery, and persistent observation of moral and cultural degradation occurring as a result of contact policies. Cant and James and Pawson, in examining the particular case of New Zealand, concentrate on the recent past and present situation as shown through claims mounted with the Waitangi Tribunal. They highlight important issues concerning not only the role of the tribunal in dealing with events during the time elapsed since the original Treaty but also problems concerning conflicting information within the Maori community. McIntyre approaches these issue from a somewhat different direction, describing conflicts and negotiations arising from land tenure allocations in southern Arizona.

\section{Assimilation}

Parry and Taffe both examine issues concerning Australia's policies promoting the assimilation of its indigenous minority peoples. They highlight different themes and offer analyses on very different scales. Parry identifies racially based ideas of non-Aboriginal superiority as fundamental to the process of removing 'half-caste' children from their Aboriginal mothers; while Taffe explores the Australian government's defensive responses to increasing international publicity about Aboriginal policies and issues in the crucial period of the early 1960 s, immediately prior to the referendum.

\section{Contemporary Indigenous Networks}

Jull's commentary, focusing on the circumpolar movement which has linked Inuit/Eskimo/Sami peoples from Alaska, Canada, Greenland and Scandinavia, discusses how such a network has helpd to empower indigenous minority groups in their negoiations with the majority and speculates on how that experince might be used by other such peoples, including those from the southern hemisphere. It provides a fitting conclusion for the whole collection. 